\title{
Green supply chain management in small and medium enterprises: Further empirical thoughts from South Africa
}

\begin{tabular}{|c|c|}
\hline \multicolumn{2}{|c|}{$\begin{array}{l}\text { Authors: } \\
\text { Louis R. Epoh }{ }^{1} \text { (1) } \\
\text { Chengedzai Mafini }{ }^{2} \text { (]) }\end{array}$} \\
\hline \multicolumn{2}{|c|}{$\begin{array}{l}\text { Affiliations: } \\
{ }^{1} \text { Graduate School of Business } \\
\text { Leadership, University of } \\
\text { South Africa, South Africa }\end{array}$} \\
\hline \multicolumn{2}{|c|}{$\begin{array}{l}{ }^{2} \text { Department of Logistics, } \\
\text { Vaal University of Technology, } \\
\text { South Africa }\end{array}$} \\
\hline \multicolumn{2}{|c|}{$\begin{array}{l}\text { Corresponding author: } \\
\text { Chengedzai Mafini, } \\
\text { chengedzai@hotmail.com }\end{array}$} \\
\hline \multicolumn{2}{|c|}{$\begin{array}{l}\text { Dates: } \\
\text { Received: } 20 \text { Mar. } 2018 \\
\text { Accepted: } 03 \text { May } 2018 \\
\text { Published: } 21 \text { June } 2018\end{array}$} \\
\hline \multicolumn{2}{|c|}{$\begin{array}{l}\text { How to cite this article: } \\
\text { Epoh, L.R. \& Mafini, C., 2018, } \\
\text { 'Green supply chain } \\
\text { management in small and } \\
\text { medium enterprises: Further } \\
\text { empirical thoughts from } \\
\text { South Africa', Journal of } \\
\text { Transport and Supply Chain } \\
\text { Management 12(0), a393. } \\
\text { https://doi.org/10.4102/ } \\
\text { jtscm.v12i0.393 }\end{array}$} \\
\hline \multicolumn{2}{|c|}{$\begin{array}{l}\text { Copyright: } \\
\text { ( } 2018 \text {. The Authors. } \\
\text { Licensee: AOSIS. This wor } \\
\text { is licensed under the } \\
\text { Creative Commons } \\
\text { Attribution License. }\end{array}$} \\
\hline \multicolumn{2}{|c|}{ Read online: } \\
\hline 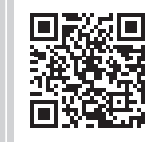 & $\begin{array}{l}\text { Scan this QR } \\
\text { code with your } \\
\text { smart phone or } \\
\text { mobile device } \\
\text { to read online. }\end{array}$ \\
\hline
\end{tabular}

Background: For South African small and medium enterprises (SMEs) to gain and maintain competitive advantages and succeed, they have to change their practices and adapt their strategies to the dynamic environment of today. A better understanding and application of green supply chain management practices by SMEs could enable such enterprises to improve their performance and succeed in their operations.

Objectives: This study aimed to analyse the relationship between green supply chain management, environmental performance and supply chain performance in South African SMEs.

Method: A conceptual model was proposed and subjected to empirical verification using data collected from SMEs based in Gauteng province. The structural equation modelling procedure was used to test hypotheses in the proposed relationships in SMEs within different industries.

Results: The results of the study indicated mixed outcomes. No relationships were found between environmental performance and two green supply chain dimensions, namely green purchasing and eco-design. However, the remaining dimensions of green supply chain management, namely reverse logistics and legislation and regulation, positively and significantly predicted environmental performance. In turn, environmental performance positively and significantly predicted supply chain performance.

Conclusion: Integrating green supply chain management practices, especially reverse logistics and adherence to legislation and regulation into the SME business strategy, leads to the improvement of environmental and overall supply chain performance.

\section{Introduction}

Over the past few decades, green supply chain management (GSCM) has gained popularity across the world, mainly in developed countries but in developing nations as well (Govindan et al. 2014). This interest in GSCM is driven by the efforts of governments and other institutions to either prevent or limit the disastrous effects of industry-related activities on the environment (Wong, Wong \& Boonitt 2015). Consequently, many organisations worldwide have begun to show a high level of commitment to GSCM through the implementation of environmental practices that are intended to reduce and preserve the degradation of the environment (Tiwari, Chang \& Choudhary 2015). The practice of GSCM extends the traditional concept of supply chain management by providing an improvement of products and services that are environmentally friendly across their complete life-cycle (Ahi \& Searcy 2015; Gunasekaran, Subramanian \& Rahman 2015; Rostamzadeh et al. 2015). Integrating green practices in organisational strategy helps to increase not only efficiency but also the overall performance of the firm (Srivastava 2008). However, despite the increased popularity of GSCM in many countries, there are still several areas that require further research, mainly as greening the supply chain has been identified as a key issue of sustainable supply chain management (Green et al. 2012; Large \& Thomsen 2011). In particular, research on GSCM still has to be extended to small to medium enterprises (SMEs) as the majority of studies conducted have been confined to large organisations (Ahi \& Searcy 2013).

In South Africa, the economic contributions of SMEs are well documented in the available literature (Kongolo 2010; Maduku, Mpinganjira \& Duh 2016; The Banking Association of South Africa 2017). Nevertheless, in spite of their contributions to the economic growth of South Africa, the success of SMEs is hindered by an assortment of challenges, which include the lack of access 
to financing, the lack of skills, the lack of systems that attract and retain experienced managers and the lack of formalised organisational structures, amongst others (Cant \& Wiid 2013; Kengne 2016; Pretorius 2009). The Small Enterprises Development Agency (2016) indicates that the failure rate of SMEs in South Africa lies around an alarming 71\%, which suggests that these enterprises have to adopt other strategies to disrupt this negative trajectory and to stimulate growth. Thus, as indicated by Urban and Naidoo (2012), SMEs in South Africa have to continually reinvent their strategies to be able to sustain their operations and take advantage of opportunities.

This study aimed to analyse the relationship between GSCM, environmental performance and supply chain performance (SCP) in South African SMEs. Despite concerted efforts by the South African government to promote SMEs, there are still widespread and high incidences of failure in this sector of the economy (Fatoki 2014; Kalane 2015; Ramukumba 2014). The World Economic Forum (2016) ranks South Africa as one of the lowest in terms of competitiveness in the SME sector. As a result of these mounting challenges, it is crucial that sustainable solutions to increase the chances of survival and success of SMEs in South Africa be found. This study presupposes that assuming GSCM practices could be a solution in the bid to increase the performance of SMEs and hence prevent their inadvertent failure. Environmentalists across the world are working hard to help SMEs consider embracing and implementing GSCM to reap the benefits associated with it (Mohanty \& Prakash 2014; Rettie, Burchell \& Riley 2012). Moreover, as put forward by several scholars (Ahi \& Searcy 2013; Liu et al. 2011; Rettie et al. 2012), the application of GSCM results in benefits that include high operational efficiency, satisfactory financial performance and a good reputation, amongst others. In view of this, beleaguered enterprises such as South African SMEs stand to realise these benefits and hence excel in their operations should they implement GSCM practices.

In addition to the above, a literature search for studies on GSCM amongst South African SMEs revealed a lack of previous studies. The major studies available (Mafini \& Muposhi 2017; Van Rensburg 2015) disregarded the relationship dimensions under consideration in the current study, thereby proving a research gap that still has to be filled. Still, the present study is significant in several ways. Firstly, the advent of globalisation and the collapse of trade barriers have increased the pressure on organisations to improve their environmental, economic and social performance. Hence, the insight of this study cannot be overlooked as it provides owners and managers in SMEs with the understanding of how GSCM practices impact on the performance of their businesses. Secondly, for organisations to survive in today's highly competitive setting, they have to either change their practices or adapt their strategies to the ever-changing business environment. Given this background, the current study provides green supply chain professionals with adequate knowledge that will enable them to reconfigure their processes and strategies. Last but not least, the research benefits other individuals as well as scholars interested in the field of GSCM by providing them with current information.

\section{Theoretical background}

The literature review examines the constructs under consideration in this study (GSCM practices, environmental performance and SCP) as well as the research context (SMEs).

\section{Green supply chain management}

Green supply chain management is defined as a strategic capability consisting of strategies, practices and policies that concentrate on managing the environmental impact of supply chain operations (Rauer \& Kaufmann 2015). It may also refer to the integration of ecological thinking into supply chain management, including product design, material sourcing and selection, manufacturing process, delivery of the final product to the consumers as well as the end-of-life management of a product after its useful life (Srivastava 2007). These definitions implicitly include an ecosystem philosophy of decreasing externalities (waste and pollution) and materials recovery while still focusing on the economic benefits of environmental responsibility (Griggs et al. 2013; Zhu \& Sarkis 2004). For many organisations, GSCM is a way to demonstrate their sincere commitment to sustainability (Bacallan 2000).

Much research on GSCM has focused on the functional areas of supply chain management such as purchasing and supply management (Carter \& Dresner 2001; Mollenkopf et al. 2010). However, according to Sarkis (2012), the integration of environmental issues and supply chain management has become a thriving subfield over the past few decades. The potential benefits associated with GSCM include enhanced reputation, increased efficiency, effectiveness, differentiation and revenue growth (Golicic \& Smith 2013; Rao \& Holt 2005; Wu \& Pagell 2011). Furthermore, being 'green' is also important from a long-term economic perspective because without natural resources, both business and the consumption of goods are severely stifled (Bell, Mollenkopf \& Stolze 2013). Golicic and Smith (2013) found evidence of positive tangible economic and ecological outcomes associated with GSCM practices. Also, according to Lamming and Hampson (1996), GSCM practices can be categorised into green purchasing, eco-design (ED), reverse logistics (RL) and legislation and regulation (LR). The implementation of these practices has an impact on the operations of businesses throughout the supply chain.

\section{Green purchasing}

Green purchasing refers to the practice of cooperating with suppliers to develop products that are environmentally sustainable (Carter \& Carter 1998; Zhu, Sarkis \& Lai 2008). According to Lee (2008), a buying organisation with a GSCM initiative will pay attention to green practices of their 
suppliers by deploying collaboration-based activities that include training, environmental information sharing and joint research. Other organisations may opt for a less collaborative approach by merely demanding that their suppliers make use of environmental systems such as ISO 14001. External motivators, particularly customer pressure, are key drivers of the adoption of ISO 14001 (HerasSaizarbitoria, Landin \& Molina-Azorin 2011; Vachon \& Klassen 2007). Other aspects of green purchasing include the facilitation of recycling, reuse and resource reduction (Diabat \& Govindan 2011). There is also evidence that some organisations adopt compliance and evaluative approaches to the green purchasing practices of their suppliers (Large \& Thomsen 2011). This involves evaluation of suppliers based on environmental criteria and a requirement for suppliers to develop and maintain some form of the environmental management system (EMS) (Large \& Thomsen 2011; Min \& Galle 2001; Sarkis 2012; Zhu, Sarkis \& Geng 2005). These insights lead to the following hypothesis:

H1: Implementation of green purchasing improves SME environmental performance.

\section{Eco-design}

Eco-design is concerned with the design of products that minimise the consumption of materials and energy, which facilitate the reuse, recycle and recovery of component materials and parts, and that avoid or reduce the use of hazardous products within the manufacturing process (Zhu et al. 2008). The importance of ED was identified by Buyukozkan and Cifci (2012) when they revealed that about $80 \%$ of product-related effects on the environment emanate from the design. Eco-design practices fall into two main categories: product-related design and packagingrelated design. Concerning product design, Min and Galle (2001) suggested that cost-saving opportunities at the beginning of the supply chain tend to be greater and that buying organisations need to seek for opportunities to utilise recycled and reused components actively. However, $\mathrm{Wu}$ and Pagell (2011) stressed that the environmental impacts of a product occur at all stages of its life-cycle and identified life-cycle assessment as a commonly used attribute of GSCM.

Building on the theme of life-cycle impacts, Field and Sroufe (2007) noted that one of the sources of recycled materials is post-consumer waste, while Zhu et al. (2005) suggested that it is possible to sell or reuse products or their contents. The implication is that it is important for organisations to ensure that their products comprise contents that can be reused or recycled. With respect to packaging-related $E D$, a discussion of GSCM practices by Zhu et al. (2005) suggested that organisations and their suppliers should collaborate to ensure that they use green packaging for their products. Other studies have identified elements of green packaging to include ensuring that packaging is reusable and recyclable (Carter \& Carter 1998; Large \& Thomsen 2011), minimising waste by reducing packaging (Walker, Di Sisto \& McBain 2008) and avoidance of hazardous material (Buyukozkan \& Cifci 2012). These perspectives invoke the following hypothesis:

H2: Implementation of ED improves SME environmental performance.

\section{Reverse logistics}

Reverse logistics refers to a flow of products or goods back from the consumer to an earlier stage of the supply chain (Seroka-Stolka 2014). This is performed for the purpose of recycling, reusing, remanufacturing, repairing, refurbishing or ensuring safe disposal (Carter \& Ellram 1998; Younis Sundarakani \& Vel 2016). Previous literature indicates that RL activities include product returns and remanufacturing (Olorunniwo \& Li 2010), recovery, recycling and reuse (Field \& Sroufe 2007) and redistribution (Das 2012). Reverse logistics practices concern final products, their components (Das 2012) and packaging material (Field \& Sroufe 2007), which apply to both upstream and downstream of the supply chain (Lau \& Wang 2009). Just like other GSCM initiatives, RL plays an important role in enhancing the organisation's operational efficiency, improves competitiveness and reduces system-wide costs (Lau \&Wang 2009). Greening the RL networks is considered a strategic tool as it can provide lucrative economic benefits and improve organisational competitiveness (Buyukozkan \& Cifci 2012; Murphy \& Poist 2003). Reverse logistics therefore focuses on saving money and adding value to organisational performance by fostering the reuse or resell of materials in order to recover the loss of profits and reduce operational costs (Xie \& Breen 2012). These views lead to the following hypothesis:

H3: Implementation of RL improves SME environmental performance.

\section{Legislation and regulatory practices}

Legislation and regulatory practices refer to laws, policies and rules that are usually promulgated by government and other regulatory bodies for the purposes of promoting the preservation of the environment (Björklund, Martinsen \& Abrahamsson 2012). Both proactive and reactive organisations have developed effective green regulation programmes as a result of government pressure and other regulatory bodies (Chung \& Wee 2011; Sheu 2011). Chen and Sheu (2009) suggest that relevant public policies are essential in substantiating the greening of the supply chain. $\mathrm{Lu}, \mathrm{Wu}$ and Kuo (2007) further assert that many organisations give up their old practices to steadily engage in efforts to green their supply chains in response to stringent LR. These efforts include proactively addressing environmental and social issues in advance of regulation (Zailani et al. 2012). Zhu et al. (2015) stress that regulations and related programmes tend to promote energy efficiency and reduction of pollution. This leads to the following hypothesis:

H4: Adherence to LR improves SME environmental performance. 


\section{Environmental performance}

Environmental performance may be perceived as the measure of reduction of substances and emissions that reduce environmental impacts caused by business organisations (Kumar, Chattopadhyaya \& Sharma 2012). Environmental performance is usually measured in terms of reduction in air emission, energy consumption, hazardous material, material usage and compliance to environmental standards (Zhu, Tian \& Sarkis 2012). There has been an upsurge in the environmental awareness of consumers in general, together with a growing number of corporations developing company-wide environmental programmes and green products sourced from markets around the world (Delmas, Nairn-Birch \& Lim 2015; Min \& Galle 1997; Zobel 2015). Lindenberg and Steg (2007) suggest that some firms pursue ecological initiatives because their primary decision-makers have an innate concern for the environment and want to do as much good for the environment as possible. In these firms, top management is responsible for their environmental management leadership, which idealise rather than rationalise the best course of action (Hoejmose, Brammer \& Millington 2012). As such, GSCM is now recognised as a strategy for protecting the environment as well as a source of motivation which focuses on improving employee morale and individual satisfaction (Govindan et al. 2014). Besides, environmental issues have become a source of competitiveness, which also helps to improve efficiency and synergy amongst business partners and enhance environmental presence, minimise waste and achieve cost savings and firm reputation (Rao \& Holt 2005). This leads to the following hypothesis:

H5: The better the SME environmental performance, the greater the performance of the supply chain.

\section{Supply chain performance}

Supply chain performance is the operational measures that contribute to the improvement of the entire supply chain as a result of collaborative relationships amongst supply chain members (Gagalyuk, Hanf \& Hingley 2013; Nyaga et al. 2013; Odongo et al. 2016; Whipple, Lynch \& Nyaga 2010). It has also been defined as a systematic process of measuring the effectiveness and efficiency of supply chain operations (Neely, Gregory \& Platts 1995). Literature suggests that supply chain relationships create opportunities for firms to experience improved performance (Fynes, de Búrca \& Mangan 2008; Wu, Choi \& Rungtusanatham 2010). The perceived contribution of a supply chain member to SCP is typically measured using the four constructs of efficiency, responsiveness, quality and supply chain balance. Efficiency is a measure of how well resources are utilised and includes logistics costs and profits (Aramyan et al. 2007). Responsiveness is a measure of speed or rate of providing the requested products and is measured in terms of lead time and customer complaints (Aramyan et al. 2007). Quality consists of products and process quality, with product quality consisting of safety and attractiveness, while process quality is measured by environmental friendliness (Aramyan et al. 2007; Chen \& Paulraj 2004; Neely et al. 1995). Supply chain balance is defined as the distribution of risks and benefits as well as supply chain understanding. Thus, SCP promotes collaboration amongst members of the supply chain and ensures continual improvement of effectiveness and efficiency of processes (Anand \& Grover 2015; Sundram, Chandran \& Bhatti 2016).

\section{Green supply chain management challenges in small and medium scale enterprises}

In general, most SMEs are confronted with various challenges that prevent them from engaging in GSCM. Some of these challenges include the lack of financial and human resources, limited innovation capability and limited operational knowhow (Abbasi \& Nilsson 2012; Wang 2016). As observed by Chin et al. (2012), the majority of SMEs are financially constrained to implement GSCM initiatives and lack formalised organisational structures required to implement GSCM action programmes. A previous study by Preuss (2011) noted that some SMEs are of the view that a formalised corporate structure limits flexibility in decision-making. Also, implementing GSCM requires innovative technological capabilities in the realms of green design, managerial competencies in supplier evaluation and negotiation skills, which are inherently scarce in most SMEs (Mohanty \& Prakash 2014). It also requires employee training and development to instil the green corporate culture needed to roll out and sustain GSCM practices (Diabat \& Govindan 2011). However, although these challenges may prove overwhelming, GSCM remains a viable strategy in the long term through cost savings and product differentiation (Mohanty \& Prakash 2014).

\section{Conceptual model}

Figure 1 outlines the conceptual model that directed this study.

Figure 1 shows that the implementation of GSCM practices through green purchasing, ED, RL and legislation and regulatory

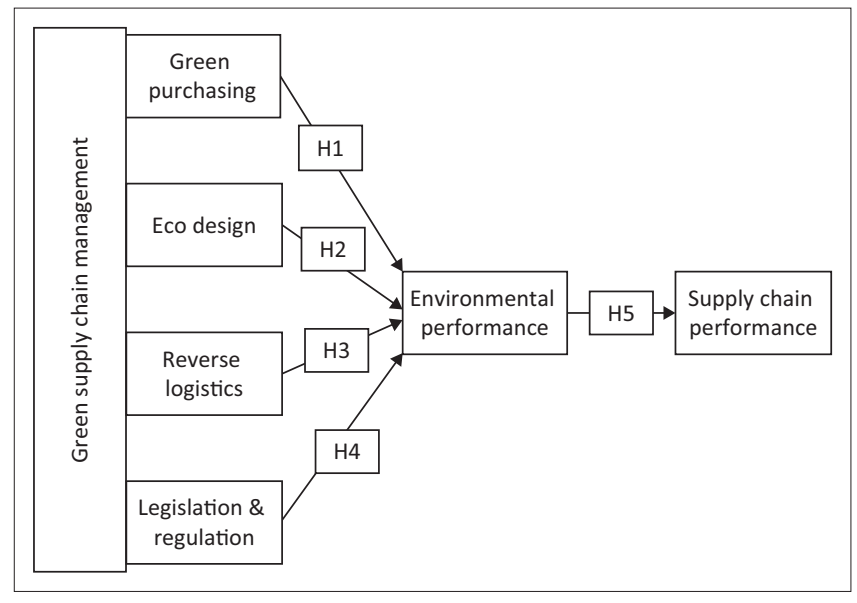

$\mathrm{H}$, hypothesis.

FIGURE 1: Conceptual model for green supply chain management, environmental performance and supply chain performance. 
practices (predictor variables) has a positive influence on the environmental performance (mediating variable), which in turn has a positive impact on SCP (outcome variable).

\section{Research method and design}

This section briefly discusses the research design, the sample, instrumentation and data analysis.

A quantitative approach was used because it facilitated the objective measurement of the variables of interest and determining the possible relationships between them (Leedy \& Ormrod 2015). The cross-sectional survey design was used to obtain the data needed for statistical testing, as questionnaires were administered once within a specific period to the sample of respondents.

\section{Sample}

The sample used in this study was composed of 65 SMEs based in Gauteng province. There was no sampling frame in this study as it was difficult to obtain a single list of all SMEs operating in South Africa. In view of this, a non-probability convenience sampling technique was used to select owners and managers of SMEs in Gauteng. The convenience sampling technique considered respondents who were readily available, and who formed part of the target population. To determine the adequacy of the sample size $(n=65)$ used in this study, two considerations were made. The first was the historical reference technique, which gave reference to previous but similar studies in supply chain management (Huang, Boon \& Xiaoming 2015; Lee 2008; Mafini \& Muposhi 2017; Younis et al. 2016). These studies used sample sizes ranging between 50 and 600 respondents. The second consideration was to use the standard put forward in a survey conducted by Wolf et al. (2013) that examined sample size requirements for common applied structural equation modelling (SEM). In that study, it was discovered that sample sizes ranging between 30 and 460 respondents produced meaningful patterns of association between parameters. Therefore, the total sample size of $n=65$ cases was accepted for data analysis in this study. The profile of the SMEs that participated in the study is presented in Table 1.

An analysis of the statistics in Table 1 indicates that manufacturing SMEs were the majority in the sample (64.6\%; $n=42$ ), followed by SMEs in the transport and electricity, gas and water industry $(10.8 \% ; n=7)$ with construction SMEs $(6.2 \% ; n=6)$ coming third. Further analyses show that $27.7 \%$ $(n=18)$ of participating SMEs employed between 21 and 50 people, while $20.0 \%(n=13)$ employed less than 20 employees. Another $20.0 \%(n=13)$ of the SMEs employed between 51 and 100 people. Concerning annual turnover, $26.2 \%(n=17)$ of the participating SMEs had an annual turnover of between R10 and R20 million, while 24.6\% $(n=16)$ had annual turnovers of less than R10 million. Another 24.6\% $(n=16)$ of SMEs had annual turnovers of less than R50 million.
TABLE 1: Profile of participating small and medium enterprises.

\begin{tabular}{|c|c|c|c|}
\hline Variable & Categories & $n$ & $\%$ \\
\hline \multirow[t]{8}{*}{ Industry classification } & Manufacturing & 42 & 64.6 \\
\hline & Construction & 6 & 9.2 \\
\hline & Retail & 1 & 1.5 \\
\hline & Agriculture & 1 & 1.5 \\
\hline & Transport & 7 & 10.8 \\
\hline & Electricity, gas and water & 7 & 10.8 \\
\hline & Finance and business services & 1 & 1.5 \\
\hline & Other & 0 & 0.0 \\
\hline Totals & & 65 & 100.0 \\
\hline \multirow[t]{6}{*}{ Number of employees } & $<20$ & 13 & 20.0 \\
\hline & $21-50$ & 18 & 27.7 \\
\hline & $51-100$ & 13 & 20.0 \\
\hline & $101-200$ & 6 & 9.2 \\
\hline & $201-300$ & 3 & 4.6 \\
\hline & $>300$ & 12 & 18.5 \\
\hline Totals & & 65 & 100.0 \\
\hline \multirow[t]{6}{*}{ Annual turnover } & $<\mathrm{R} 10 \mathrm{~m}$ & 16 & 24.6 \\
\hline & Between $\mathrm{R} 10 \mathrm{~m}$ and $\mathrm{R} 20 \mathrm{~m}$ & 17 & 26.2 \\
\hline & Between R21 m and R30 m & 9 & 13.8 \\
\hline & Between R31 m and R40 m & 4 & 6.2 \\
\hline & Between R41 $\mathrm{m}$ and R50 m & 3 & 4.6 \\
\hline & $>\mathrm{R} 50 \mathrm{~m}$ & 16 & 24.6 \\
\hline Totals & & 65 & 100.0 \\
\hline
\end{tabular}

$R$, South African currency (ZAR); $m$, million.

\section{Data collection and instrumentation}

In this study, 95 copies of the survey questionnaire were distributed to owners and managers of SMEs in Gauteng, South Africa in September 2017. A combination of e-mails and the drop and collect method was used in distributing the questionnaires to respondents. Initially, a week was given to respondents to complete the questionnaires. However, this deadline was extended to two weeks as a result of a prolonged return rate of the questionnaires. A confidentiality agreement accompanied each questionnaire to facilitate the data collection. All of the respondents completed the same questionnaire as they represented their respective SMEs. After the data collection process, a total of 67 questionnaires were returned, and 2 were discarded because they had errors. This culminated in 65 questionnaires used in the final data analysis, providing a response rate of $68 \%$. Measurement scales used in the study were operationalised using previous studies. Table 2 shows these questions and their sources.

\section{Data analysis}

To achieve the aim of the study, statistical analyses were performed using the Statistical Packages for Social Sciences (SPSS version 24.0) and the Analysis of Moments Software (AMOS version 24). Relationships between the research constructs were tested using SEM.

\section{Results of the study}

This section discusses the use of inferential statistics in this study, confirmatory factor analysis (CFA) results and the outcomes of hypotheses tests. 
TABLE 2: Measurement scales and their sources.

\begin{tabular}{|c|c|c|}
\hline Item code & Description & Sources of questions \\
\hline \multicolumn{3}{|c|}{ Green purchase } \\
\hline GP1 & $\begin{array}{l}\text { Evaluation of environmentally friendly } \\
\text { practices of second-tier supplier }\end{array}$ & Zhu et al. (2008) \\
\hline GP2 & $\begin{array}{l}\text { Providing design specification to suppliers } \\
\text { that include environmental requirements } \\
\text { for purchased items }\end{array}$ & \\
\hline GP3 & $\begin{array}{l}\text { Cooperation with suppliers for } \\
\text { environmental objectives }\end{array}$ & \\
\hline GP4 & $\begin{array}{l}\text { Consideration of suppliers' ISO } 14001 \\
\text { certification }\end{array}$ & \\
\hline GP5 & $\begin{array}{l}\text { Environmental audits for suppliers' } \\
\text { internal management }\end{array}$ & \\
\hline \multicolumn{3}{|l|}{ Eco-design } \\
\hline ED1 & $\begin{array}{l}\text { Design of products for reduced } \\
\text { consumption of material/energy }\end{array}$ & Matos and Hall (2007) \\
\hline ED2 & $\begin{array}{l}\text { Design of products for reuse, recycle, } \\
\text { recovery of material and component parts }\end{array}$ & \\
\hline ED3 & $\begin{array}{l}\text { Design of products to avoid or reduce } \\
\text { the use of hazardous products }\end{array}$ & Zhu et al. (2008) \\
\hline ED4 & $\begin{array}{l}\text { Design of processes for minimisation } \\
\text { of waste }\end{array}$ & \\
\hline ED5 & $\begin{array}{l}\text { Design of products considering life-cycle } \\
\text { assessment }\end{array}$ & \\
\hline \multicolumn{3}{|c|}{ Reverse logistics } \\
\hline RL1 & $\begin{array}{l}\text { Collect used products from customers } \\
\text { for recycling }\end{array}$ & Zailani et al. (2012) \\
\hline RL2 & $\begin{array}{l}\text { Repair and provide maintenance services } \\
\text { after sales }\end{array}$ & Carter and Ellram (1998) \\
\hline RL3 & $\begin{array}{l}\text { Recapture value through remanufacturing } \\
\text { and proper disposal of returned products }\end{array}$ & \\
\hline RL4 & Return products to suppliers for recycling & \multirow{2}{*}{$\begin{array}{l}\text { Álvarez-Gil Berrone, } \\
\text { Husillos and Lado (2007) }\end{array}$} \\
\hline RL5 & $\begin{array}{l}\text { Interaction with operations and reverse } \\
\text { logistics staff for designing reverse logistics } \\
\text { programmes }\end{array}$ & \\
\hline \multicolumn{3}{|c|}{ Legislation and regulation } \\
\hline LR1 & $\begin{array}{l}\text { Adopt green supply chain initiatives to } \\
\text { avoid the threat of legislation }\end{array}$ & Carter and Carter (1998) \\
\hline LR2 & $\begin{array}{l}\text { Strict environmental standards to } \\
\text { comply with }\end{array}$ & \\
\hline LR3 & $\begin{array}{l}\text { Frequent government inspections in } \\
\text { my firm }\end{array}$ & \\
\hline LR4 & $\begin{array}{l}\text { Embrace government imposed } \\
\text { environmental regulations }\end{array}$ & \\
\hline \multicolumn{3}{|c|}{ Environmental performance } \\
\hline EP1 & Reduction of air emission & Zhu et al. (2008) \\
\hline EP2 & Reduction of solid wastes & \\
\hline EP3 & Reduction of effluent wastes & \\
\hline EP4 & $\begin{array}{l}\text { Decrease the frequency of } \\
\text { environmental accidents }\end{array}$ & \\
\hline EP5 & $\begin{array}{l}\text { Decrease consumption of } \\
\text { hazardous and toxic materials }\end{array}$ & \\
\hline EP6 & $\begin{array}{l}\text { Improvement in an enterprise's } \\
\text { environmental situation }\end{array}$ & \\
\hline \multicolumn{3}{|c|}{ Supply chain performance } \\
\hline SCP1 & More accurate costing & Lenny Koh et al. (2007) \\
\hline SCP2 & $\begin{array}{l}\text { Increase in coordination between } \\
\text { departments }\end{array}$ & \\
\hline SCP3 & Increase in coordination with suppliers & \\
\hline SCP4 & Increase in coordination with customers & \\
\hline SCP5 & Increase in sales & \\
\hline SCP6 & Just-in-time & Li et al. (2009) \\
\hline SCP7 & Delivery performance and quality & \\
\hline
\end{tabular}

GP, scale: 1 - not considering it; 2 - planning to consider it; 3 - considering it currently; 4 -initiating implementation; 5 -implementing successfully.

ED, scale: 1 - not considering it; 2 - planning to consider it; 3 - considering it currently 4 -initiating implementation; 5 -implementing successfully.

RL, scale: 1 - not considering it; 2 - planning to consider it; 3 - considering it currently; 4 - initiating implementation; 5 -implementing successfully.

LR, scale: 1 - not considering it; 2 - planning to consider it; 3 - considering it currently; 4 -initiating implementation; 5 -implementing successfully.

EP, scale: 1 - not at all; 2 -a little bit; 3 - to some degree; 4 -relatively significant; 5 -significant. SCP, scale: 1 - much worse than industry average; 2 - somewhat worse than industry average; 3 - about the same as industry average; 4 - somewhat better than industry average; 5 - much better than the industry average.

\section{Inferential statistics}

Inferential statistics refer to statistical analyses that allow the researcher to draw inferences about large populations from relatively small samples (Leedy \& Ormrod 2015). Inferences are drawn based on tests conducted to determine the relationship between green practices and environmental performance, and the relationship between environmental performance and SCP. A two-way formula recommended by Anderson and Gerbing (1988) was used, which involves performing a CFA followed by testing the proposed research hypotheses utilising the path analysis approach.

\section{Confirmatory factor analysis}

A CFA was performed to test the reliability, validity and determine the model-fit requirements. The results of the CFA are presented in Table 3 .

The statistical results from Table 3 show that the reliability was ascertained using the Cronbach's alpha test and the composite reliability (CR). Mitchell and Jolley (1996) suggest that the values of Cronbach's alpha test that are greater than 0.7 are considered acceptable as they fulfil the requirements of internal consistency. In Table 3, the values of the Cronbach's alpha test lie between 0.866 and 0.966 , which demonstrates that the requirements for internal consistency were met. Regarding the CR test, Fornell and Lacker (1981) assert that the minimum threshold of 0.7 should be attained to confirm the acceptability of the reliability. In this study, the value of $C R$ ranged between 0.84 and 0.95 , which confirms that the minimum threshold was attained. Therefore, all measurement scales used for this study were deemed to be reliable.

Convergent validity was determined through factor loadings and average variance extracted (AVE). According to Karatepe (2006), factor loadings greater than 0.5 are deemed to be acceptable. Table 3 shows that the values of factor loadings ranged between 0.637 and 0.942 , which implies that the requirements of conversion validity were met. In addition, AVE values were above the recommended cut-off value of 0.5 (Fraering \& Minor 2006), which further confirms the adequacy of convergent validity within the scales. To check for discriminant validity, two criteria were used. Firstly, as suggested by Fornell and Larcker (1981), the AVE values for each construct should be higher than the highest shared variance (HSV) for that construct. This parameter was satisfied, as AVE values were higher than the corresponding HSV for all of the constructs. Secondly, correlations between constructs should be below a unit value of 1.0. (Fraering \& Minor 2006). As indicated in Table 5, the minimum inter-construct correlation was 0.535 . Therefore, discriminant validity was deemed acceptable in this study.

\section{Model-fit analysis}

Upon completion of the assessment of reliability and validity, the model-fit assessment was conducted for both 
TABLE 3: Statistical analysis of accuracy.

\begin{tabular}{|c|c|c|c|c|c|c|}
\hline \multirow[t]{2}{*}{ Research constructs } & \multicolumn{2}{|c|}{ Cronbach's test } & \multirow[t]{2}{*}{ CR } & \multirow[t]{2}{*}{ AVE } & \multirow[t]{2}{*}{ Highest shared variance } & \multirow[t]{2}{*}{ Factor loadings } \\
\hline & Item-total correlations & $\alpha$ value & & & & \\
\hline \multicolumn{7}{|l|}{ Green purchasing (GP) } \\
\hline $\mathrm{GP}_{1}$ & 0.888 & \multirow{5}{*}{0.94} & \multirow{5}{*}{0.93} & \multirow{5}{*}{0.78} & \multirow{5}{*}{0.72} & 0.918 \\
\hline $\mathrm{GP}_{2}$ & 0.853 & & & & & 0.896 \\
\hline $\mathrm{GP}_{3}$ & 0.893 & & & & & 0.910 \\
\hline $\mathrm{GP}_{4}$ & 0.868 & & & & & 0.906 \\
\hline $\mathrm{GP}_{5}$ & 0.790 & & & & & 0.805 \\
\hline \multicolumn{7}{|l|}{ Eco-design (ED) } \\
\hline $\mathrm{ED}_{1}$ & 0.919 & \multirow{5}{*}{0.96} & \multirow{5}{*}{0.95} & \multirow{5}{*}{0.85} & \multirow{5}{*}{0.55} & 0.942 \\
\hline $\mathrm{ED}_{2}$ & 0.902 & & & & & 0.918 \\
\hline $\mathrm{ED}_{3}$ & 0.922 & & & & & 0.943 \\
\hline $\mathrm{ED}_{4}$ & 0.875 & & & & & 0.894 \\
\hline $\mathrm{ED}_{5}$ & 0.903 & & & & & 0.920 \\
\hline \multicolumn{7}{|l|}{ Reverse logistics (RL) } \\
\hline $\mathrm{RL}_{2}$ & 0.513 & \multirow{4}{*}{0.86} & \multirow{4}{*}{0.84} & \multirow{4}{*}{0.58} & \multirow{4}{*}{0.58} & 0.660 \\
\hline $\mathrm{RL}_{3}$ & 0.831 & & & & & 0.838 \\
\hline $\mathrm{RL}_{4}$ & 0.699 & & & & & 0.734 \\
\hline $\mathrm{RL}_{5}$ & 0.760 & & & & & 0.870 \\
\hline \multicolumn{7}{|c|}{ Legislation and regulation (LR) } \\
\hline $\mathrm{LR}_{1}$ & 0.828 & \multirow{4}{*}{0.89} & \multirow{4}{*}{0.88} & \multirow{4}{*}{0.72} & \multirow{4}{*}{0.58} & 0.903 \\
\hline $\mathrm{LR}_{2}$ & 0.803 & & & & & 0.889 \\
\hline $\mathrm{LR}_{3}$ & 0.587 & & & & & 0.637 \\
\hline $\mathrm{LR}_{4}$ & 0.881 & & & & & 0.940 \\
\hline Environmental perfor & & & & & & \\
\hline $\mathrm{EP}_{1}$ & 0.795 & & & & & 0.790 \\
\hline $\mathrm{EP}_{2}$ & 0.812 & & & & & 0.795 \\
\hline $\mathrm{EP}_{3}$ & 0.896 & 0.95 & 0.94 & 0.76 & 0.70 & 0.920 \\
\hline $\mathrm{EP}_{4}$ & 0.845 & & & & & 0.866 \\
\hline Supply chain perform & & & & & & \\
\hline $\mathrm{SPC}_{1}$ & 0.784 & & & & & 0.804 \\
\hline $\mathrm{SPC}_{2}$ & 0.850 & & & & & 0.906 \\
\hline $\mathrm{SPC}_{3}$ & 0.872 & & & & & 0.903 \\
\hline $\mathrm{SPC}_{4}$ & 0.832 & 0.932 & 0.92 & 0.68 & 0.55 & 0.893 \\
\hline $\mathrm{SPC}_{5}$ & 0.685 & & & & & 0.717 \\
\hline $\mathrm{SPC}_{6}$ & 0.693 & & & & & 0.708 \\
\hline $\mathrm{SPC}_{7}$ & 0.832 & & & & & 0.832 \\
\hline
\end{tabular}

$\mathrm{CR}$, composite reliability; AVE, average variance extracted.

$\alpha$, Cronbach's alpha.

TABLE 4: Model-fit statistics.

\begin{tabular}{lccc}
\hline Fit indices & $\begin{array}{c}\text { Acceptable fit } \\
\text { indices }\end{array}$ & $\begin{array}{c}\text { CFA } \\
\text { (Measurement } \\
\text { model) }\end{array}$ & $\begin{array}{c}\text { SEM } \\
\text { (Structural } \\
\text { model) }\end{array}$ \\
\hline $\begin{array}{l}\text { Chi-square/degree of } \\
\text { freedom (d/f) }\end{array}$ & $<3.0$ & 2.149 & 2.476 \\
$\begin{array}{l}\text { Incremental fit index (IFI) } \\
\text { Tucker-Lewis index (TLI) }\end{array}$ & $>0.90$ & 0.903 & 0.940 \\
Comparative fit index (CFI) & $>0.90$ & 0.979 & 0.915 \\
Goodness-of-fit index (GFI) & $>0.90$ & 0.900 & 0.937 \\
Root mean square error of & $<0.08$ & 0.986 & 0.931 \\
approximation (RMSEA) & & 0.034 & 0.052 \\
\hline
\end{tabular}

CFA, confirmatory factor analysis; SEM, structural equation modelling.

CFA and SEM to determine if the data were fitting both the measurement and structural models (Westland 2015). Acceptable model-fit was determined by indices that include the chi-square value over degree of freedom (c2/ d.f.) of a value $\leq 3$, with the values of goodness-of-fit index (GFI), comparative fit index (CFI), incremental fit index (IFI) and Tucker-Lewis index (TLI) equal or greater than
0.90, and the root mean square error of approximation (RMSEA) value to be equal to or less than 0.08. Table 4 provides the results of the model-fit analysis.

The analysis of the results in Table 4 shows that the model-fit for both CFA and SEM were acceptable as they satisfied the suggested thresholds for each indicator.

Table 5 displays the correlation between constructs.

\section{Hypotheses tests}

Model-fit analysis for the structural model revealed that all model fits were within the acceptable range and are as follows: $(\mathrm{d} / \mathrm{f})=2.476 ; \quad(\mathrm{IFI})=0.940 ; \quad(\mathrm{TLI})=0.915$; $(\mathrm{CFI})=0.937 ;(\mathrm{NFI})=0.931 ;$ and $(\mathrm{RMSEA})=0.052$. Individual hypotheses test results are presented in Table 6 . The study tested hypotheses using the path analysis procedure. The results are reported in Table 6. 
TABLE 5: Correlations between constructs.

\begin{tabular}{|c|c|c|c|c|c|c|}
\hline Constructs & GP & ED & $\mathbf{R L}$ & LR & EP & SCP \\
\hline Green purchasing (GP) & 1.000 & - & - & - & - & - \\
\hline Eco-design (ED) & $0.849 *$ & 1.000 & - & - & - & - \\
\hline Reverse logistics (RL) & $0.731 *$ & $0.739 *$ & 1.000 & - & - & - \\
\hline Legislation and regulation (LR) & $0.762 *$ & $0.680^{*}$ & $0.589 *$ & 1.000 & - & - \\
\hline Environmental performance (EP) & $0.732 *$ & $0.657^{*}$ & $0.722^{*}$ & $0.836^{*}$ & 1.000 & - \\
\hline Supply chain performance (SCP) & $0.535 *$ & $0.544 *$ & $0.743 *$ & $0.543 *$ & $0.665 *$ & 1.000 \\
\hline
\end{tabular}

GP, green purchasing; ED, eco-design; RL, reverse logistics; LR, legislation and regulation; EP, environmental performance; SCP, supply chain performance.

$*$, significant at $p<0.05$

\begin{tabular}{|c|c|c|c|c|c|}
\hline Paths & Hypothesis & Path coefficients & Standardised estimate & $p$ & Hypotheses results \\
\hline $\mathrm{GP} \rightarrow \mathrm{EP}$ & $\mathrm{H} 1$ & 0.116 & 0.063 & 0.168 & Not supported \\
\hline $\mathrm{ED} \rightarrow \mathrm{EP}$ & $\mathrm{H} 2$ & -0.006 & 0.057 & 0.946 & Not supported \\
\hline $\mathrm{RL} \rightarrow \mathrm{EP}$ & $\mathrm{H} 3$ & 0.390 & 0.090 & 0.000 & Supported \\
\hline $\mathrm{LR} \rightarrow \mathrm{EP}$ & $\mathrm{H} 4$ & 0.721 & 0.103 & 0.000 & Supported \\
\hline $\mathrm{EP} \rightarrow \mathrm{SCP}$ & H5 & 0.611 & 0.117 & 0.000 & Supported \\
\hline
\end{tabular}

GP, green purchasing; ED, eco-design; RL, reverse logistics; LR, legislation and regulation; EP, environmental performance; SCP, supply chain performance. Significant at $p<0.001$.

The path coefficients of the proposed hypotheses ( $\mathrm{H} 1, \mathrm{H} 2$, H3, H4 and H5) are as follows: $0.116 ;-0.006 ; 0.390 ; 0.721$; and 0.611 , respectively. Except for $\mathrm{H} 1$ and $\mathrm{H} 2$, all of the other path coefficients were significant at a confidence level of 0.001 . This implies that the results from $\mathrm{H} 1$ and $\mathrm{H} 2$ do not support the proposed research hypotheses, while $\mathrm{H} 3, \mathrm{H} 4$ and $\mathrm{H} 5$ support them.

\section{Discussion}

The results in Table 6 show that three hypotheses $(\mathrm{H} 3, \mathrm{H} 4$ and H5) were supported, while two hypotheses (H1 and H2) were not supported.

\section{Green purchasing and environmental performance}

The first hypothesis (H1) of the study suggested that the implementation of GP leads to improved SME environmental performance. This hypothesis was not supported in this study because it showed statistical insignificance and an almost negligible positive relationship ( $\beta=0.116 ; p=0.168)$. This result implies that there is no relationship between GP and environmental performance. It contradicts previous studies (Carter \& Ellram 1998; Min \& Galle 2001) where positive relationships between GP and environmental performance were observed. However, the results of the study are supported by a survey conducted by Large and Thomsen (2011), which found no relationship between GP and environmental performance. The results of this study could be attributed to the inability of SMEs in South Africa to incorporate green practices into their organisational strategy and, hence, they cannot pursue the route of sustainability during purchases. Furthermore, engaging in green initiatives requires substantial capital investments that SMEs usually do not possess. This lack of financial resources may limit their affordability. The results could also be attributed to the view that the owners and managers in SMEs are yet to familiarise themselves with the benefits of implementing green practices. It could further be that SMEs do not have trained and experienced personnel committed to green initiatives and, hence, they are yet to realise the importance of these initiatives.

\section{Eco-design and environmental performance}

The second hypothesis (H2) suggested that the implementation of ED leads to improved SME environmental performance. This hypothesis was not supported in this study as there was a negative and insignificant relationship between ED and environmental performance $(\beta=-0.006$; $p=0.946)$. These results challenge previous studies conducted by Laosirihongthong et al. (2013) who assert that there is a positive relationship between ED and environmental performance. However, the present study finds support in previous studies (Montabon, Sroufe \& Narasimhan 2007; Richey et al. 2005) where evidence of a negative relationship between ED and environmental performance was found. The results of the current study could be attributed to the view that ED is too costly to implement, making it difficult for SMEs to consider it in their operations. This is because the implementation of ED requires expensive technologies coupled with extensive research and development processes, many of which are beyond the capacity of South African SMEs. For the few SMEs that have adequate financial resources, it could be that they perceive that ED is impractical for them to adopt or they merely fail to foresee any gain in implementing it.

\section{Reverse logistics and environmental performance}

The third hypothesis (H3) suggested that the implementation of RL leads to improved SME environmental performance. The hypothesis was supported in this study as the results revealed a moderate, positive and significant relationship between RL and environmental performance $\beta=0.390$; $p=0.000)$. A previous study conducted by Diabat, Khodaverdi and Olfat (2013) to explore the relationship between RL and environmental performance found that RL positively impacts environmental performance. This moderate relationship observed in the current study may imply that some SMEs perceive RL to be very expensive to implement. It could also be that some SMEs do not understand precisely the role of recycling in the success of their businesses or they have just decided to discard RL practices and are more inclined to 
other green practices. Lau and Wang (2009), in their study, found that the embracing of RL is often negatively affected by the lack of law enforcement, high costs and low public awareness on environmental sustainability. This study suggests that these adverse factors may also apply to SMEs in South Africa.

\section{Legislation and regulation and environmental performance}

The fourth hypothesis (H4) suggested that adherence to LR leads to higher SME environmental performance. This hypothesis was supported in this study, as justified by the strong positive and significant relationship between the two variables $(\beta=0.721 ; p=0.000)$. This implies that governmentimposed LR contribute to improving the environmental performance of SMEs. A study conducted by Laosirihongthong et al. (2013) supports this result as it also reached a similar conclusion. Perhaps, the respect for environmental regulations could be attributed to the fear of consequences related to non-compliance. This study suggests that to hedge themselves against reprisals by the long arm of the law, SMEs implement defensive and reactional strategies through their adherence to existing environmental laws. Adherence to these laws leads to better environmental performance. It is also noteworthy that LR scored the highest beta when compared to the other GSCM practices. This top beta score confirms the high level of importance that SMEs attach to LR regarding the pollution of the environment.

\section{Environmental performance and supply chain performance}

The fifth hypothesis (H5) suggested that the better the SME environmental performance, the higher the performance of the supply chain. A strong positive and significant relationship between these two constructs was observed ( $\beta=0.611 ; p=0.000)$ to support the hypothesis. This result corresponds with previous studies (Green, Whitten \& Inman 2011; Vachon \& Klassen 2007) which suggest that integrating environmental sustainability into organisational strategy positively impacts on the performance of the supply chain. This result may imply that SMEs understand the benefits of environmental performance and are willing to manipulate this positive effect to stimulate the performance of the supply chain. In the view of these results, it is confirmed that embracing environmental sustainability leads to improved SCP.

\section{A comprehensive green supply chain management model}

Figure 2 is the resultant structural model of the relationships between GSCM, environmental performance and supply chain performance.

The comprehensive structural model shows the extent of the relationships between the constructs related to this study as well as the factor loadings for each item in the constructs. Green purchase (GP) practices have a positive but weak and insignificant relationship with environmental performance

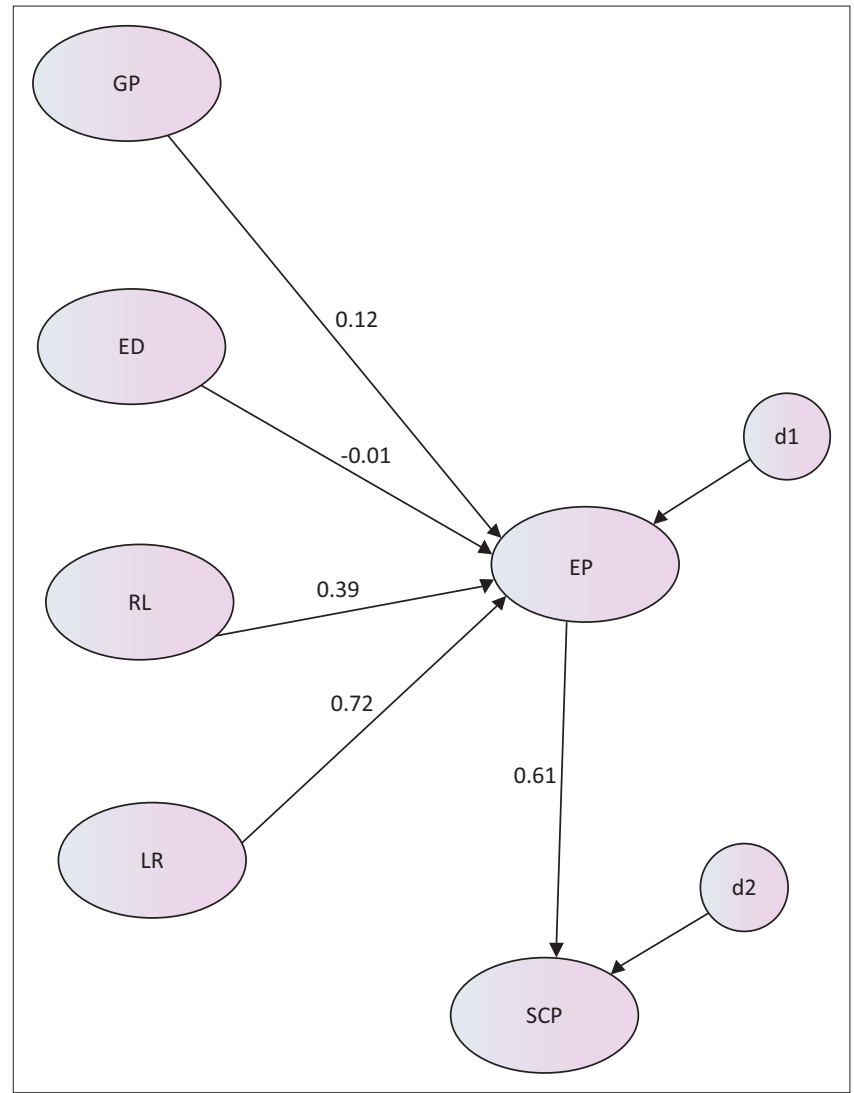

GP, green purchasing; ED, eco-design; RL, reverse logistics; $L R$, legislation and regulation; $E P$, environmental performance; $S C P$, supply chain performance.; $d_{1}$, dependant variable 1 ; $\mathrm{d}_{2}$, dependant variable 2

FIGURE 2: Structural model for green supply chain management practices, environmental performance and supply chain performance.

$(r=0.12 ; p=0.168)$. Eco-design has a negative and insignificant relationship with environmental performance $(r=-0.01$; $p=0.946)$. Reverse logistics has a positive and significant relationship with environmental performance $(r=0.39$; $p=0.000$ ). Legislation and regulation have a strong positive and significant relationship with environmental performance $(r=0.72 ; p=0.000)$. Finally, environment performance and supply chain performance have a strong positive and significant connection $(r=0.72 ; p=0.000)$. A glance at this model demonstrates that legislation and regulatory practices have the highest influence on environmental performance $(r=0.72)$.

\section{Conclusions and managerial implications}

This study aimed to analyse the relationship between GSCM practices, environmental performance and SCP amongst SMEs. Data were collected from 65 SMEs that were based in the Gauteng province of South Africa. The first part of the statistical analyses tested the relationship between environmental performance and four GSCM practices, namely GP, ED, RL and LR. The study revealed that there was no significant relationship between environmental performance and two GSCM practices, namely GP and ED. However, positive and significant relationships were established between environmental performance and two GSCM practices, namely RL and LR. The second part of the 
statistical analyses tested the relationship between environmental performance and SCP. The result of that analysis yielded a positive and significant relationship between the two factors. The study, therefore, concludes that although literature confirms the positive contribution of GSCM to environmental performance, the reality is that in SME supply chains it is necessary to ascertain the exact relationship between specific GSCM sub-dimensions and the intended performance outcome. In this case, only the implementation of RL and adherence to LR by SMEs can lead to positive results realisable through increases in both environmental and SCP.

The present study has managerial implications, which are focused on how GSCM practices can be harnessed for the improvement of performance in SMEs. Businesses within the SME sector should evaluate their suppliers based on environmental criteria and encourage them to develop and maintain some form of the EMS. In this regard, it is important to engage those suppliers that have ISO 14001 certification only, which ensures that these suppliers have a concern for the environment in their operations. Moreover, SMEs should still endeavour to design products that reduce the consumption of materials and energy, and facilitate the reuse, recycling and recovery of materials and parts. Investments in innovative RL technology should be encouraged amongst SMEs and they should consider outsourcing where there is lack of competency. It is further essential that SMEs create synergy with customers to recover all used products for recycling. Effective green regulation programmes can be developed by SMEs, which should also apply effort in complying with relevant public policies. Environmental and social issues should be addressed proactively in advance of regulation.

\section{Limitations and implications for further research}

Limitations should be highlighted so that other research orientations can be explored. This study was limited only to SMEs in Gauteng province, South Africa, and respondents were drawn from 65 business organisations. For quantitative descriptive research, this sample size was not large enough to facilitate the generalisation of the results to other environments. The study was further limited in its use of convenience sampling to select participating SMEs, which may have led to sampling bias. However, appropriate actions were taken to minimise sampling bias as the participating SMEs were selected from different locations across Gauteng.

Green practices in this study were limited to GP, ED, RL and LR dimensions. Other dimensions of the GSCM practices should be explored in future studies. Future research should consider having larger sample sizes to maximise the validity and reliability of the study. Similar studies can also be conducted in other provinces of South Africa and across the African continent.

\section{Acknowledgements}

The authors thank the SMEs that participated in this study for their input and the Graduate School of Business Leadership at University of South Africa (UNISA) for granting the permission to conduct the study.

\section{Competing interests}

The authors declare that they have no financial or personal relationships that may have inappropriately influenced them in writing this article.

\section{Authors' contributions}

L.R.E. did the literature review and collected the data, while C.M. performed the data analysis and compiled the sections of the article.

\section{References}

Abbasi, M. \& Nilsson, F., 2012, 'Themes and challenges in making supply chains environmentally sustainable', Supply Chain Management: An International Journal 17(5), 517-530. https://doi.org/10.1108/13598541211258582

Ahi, P. \& Searcy, C., 2013, 'An analysis of metrics used to measure performance in green and sustainable supply chains', Journal of Cleaner Production 86, 360-377. https://doi.org/10.1016/j.jclepro.2014.08.005

Ahi, P. \& Searcy, C., 2015, 'Measuring social issues in sustainable supply chains', Measuring Business Excellence 19(1), 33-45. https://doi.org/10.1108/MBE-11-2014-0041

Álvarez-Gil, M., Berrone, P., Husillos, F. \& Lado, N., 2007, 'Reverse logistics, stakeholders' influence, organizational slack, and managers' posture', Journal of Business Research 60(5), 463-473.

Anand, N. \& Grover, N., 2015, 'Measuring retail supply chain performance', Benchmarking: An International Journal 22(1), 135-166.

Anderson, J.C. \& Gerbing, D.W., 1988, 'Structural equation modelling in practice: A review and recommended two-step approach', Psychological Bulletin 103(3), 411-423. https://doi.org/10.1037/0033-2909.103.3.411

Aramyan, L.H., Lansink, A.G.O., Van Der Vorst, J.G. \& Van Kooten, O., 2007 'Performance measurement in agri-food supply chains: A case study'. Supply Chain Management: An International Journal 12(4), 304-315.

Bacallan, J.J., 2000, 'Greening the supply chain', Business and Environment 6(5), 11-12.

Bell, J.E., Mollenkopf, D.A. \& Stolze, H.J., 2013, 'Natural resources scarcity and the closed-loop supply chain. A resource-advantage view', International Journal of
Physical Distribution \& Logistics Management 43(5), 351-379. https://doi.org/ Physical Distribution \& Logistics
$10.1108 /$ IJPDLM-03-2012-0092

Björklund, M., Martinsen, U. \& Abrahamsson, M., 2012, 'Performance measurements in the greening of supply chains', Supply Chain Management: An International Journal 17(1), 29-39. https://doi.org/10.1108/13598541211212186

Buyukozkan, G. \& Cifci, G., 2012, 'Evaluation of green supply chain management practices: A fuzzy ANP approach', Production Planning \& Control 23(6), 405-418. https://doi.org/10.1080/09537287.2011.561814

Cant, M.C. \& Wiid, J.A., 2013, 'Establishing the challenges affecting South African SMEs', International Business \& Economics Research Journal 12(6), 707-716. https://doi.org/10.19030/iber.v12i6.7869

Carter, C. \& Ellram, L., 1998, 'Reverse logistics. A review of the literature and framework for future investigation', Journal of Business Logistics 19(1), 85-102.

Carter, C.R. \& Carter, J.R., 1998, 'Inter-organizational determinants of environmental purchasing: Initial evidence from the consumer products industries', Decision Sciences 29(3), 659-684. https://doi.org/10.1111/j.1540-5915.1998.tb01358.x

Carter, C.R. \& Dresner, M., 2001, 'Purchasing's role in environmental management: Cross-functional development of grounded theory', The Journal of Supply Chain Management 37(3), 12-27. https://doi.org/10.1111/j.1745-493X.2001.tb00102.x

Chen, I.J. \& Paulraj, A., 2004, 'Towards a theory of supply chain management: The constructs and measurements', Journal of Operations Management 22(2), 119-150. https://doi.org/10.1016/j.jom.2003.12.007

Chen, Y. \& Sheu, J.B., 2009, 'Environmental regulation pricing strategies for green supply chain management', Transportation Research Part E 45, 667-677.

Chin, A.I., Hamida, A.B.A., Raslia, A. \& Baharun, R., 2012, 'Adoption of supply chain management in SMEs', Procedia - Social and Behavioural Sciences 65, 614-619. https://doi.org/10.1016/j.sbspro.2012.11.173

Chung, C.-J. \& Wee, H.-M., 2011, 'Short life-cycle deteriorating product remanufacturing in a green supply chain inventory control system', International Journal of Production Economics 129(1), 195-203. https://doi.org/10.1016/j ijpe.2010.09.033

Das, K., 2012, 'Integrating reverse logistics into the strategic planning of a supply chain', International Journal of Production Research 50(5), 1438-1456. https:// doi.org/10.1080/00207543.2011.571944 
Delmas, M.A., Nairn-Birch, N. \& Lim, J., 2015, 'Dynamics of environmental and financial performance: The case of greenhouse gas emissions', Organization \& financial performance: The case of greenhouse gas emissions', Organization
Environment 28(4), 374-393. https://doi.org/10.1177/1086026615620238

Diabat, A. \& Govindan, K., 2011, 'An analysis of the drivers affecting the implementation of green supply chain management', Resources, Conservation and Recycling 55, 659-667. https://doi.org/10.1016/j.resconrec.2010.12.002

Diabat, A., Khodaverdi, R. \& Olfat, L., 2013, 'An exploration of green supply chain practices and performance in an automotive industry', International Journal of Advanced Manufacturing Technology 68(1), 949-961. https://doi.org/10.1007/ s00170-013-4955-4

Fatoki, O., 2014, 'The causes of the failure of new small and medium enterprises in South Africa', Mediterranean Journal of the Social Sciences 5(20), 922-927. https://doi.org/10.5901/mjss.2014.v5n20p922

Field, J. \& Sroufe, R., 2007, 'The use of recycled materials in manufacturing: Implications for supply chain management and operations strategy', Internationa Journal of Production Research 45(18), 4439-4463. https://doi.org/10.1080/ 00207540701440287

Fornell, C. \& Larcker, D.F., 1981, 'Evaluating structural equation models with unobservable variables and measurement error', Journal of Marketing Research 18, 39-50. https://doi.org/10.2307/3151312

Fraering, M. \& Minor, M.S., 2006, 'Sense of community: An exploratory study of US consumers of financial services', International Journal Bank Marketing 24, 284-306. https://doi.org/10.1108/02652320610681738

Fynes, B., de Búrca, S. \& Mangan, J., 2008, 'The effect of relationship characteristics on relationship quality and performance', International Journal of Production Economics 111(1), 56-69. https://doi.org/10.1016/j.ijpe.2006.11.019

Gagalyuk, T., Hanf, J. \& Hingley, M., 2013, 'Firm and whole chain success: Network management in the Ukrainian food industry', Journal on Chain and Network Science 13(1), 47-70. https://doi.org/10.3920/JCNS2013.x226

Golicic, S.L. \& Smith, C.D., 2013, 'A meta-analysis of environmentally sustainable supply chain management practices and firm performance', Journal of Supply Chain Management 49(2), 78-95. https://doi.org/10.1111/jscm.12006

Govindan, K., Kaliyan, M., Kannan, D. \& Haq, A.N., 2014, 'Barriers analysis for green supply chain management implementation in Indian industries using analytic
hierarchy process', International Journal of Production Economics 147, 555-568. hierarchy process', International Journal of Prc
https://doi.org/10.1016/j.ijpe.2013.08.018

Green Jr, K.W., Whitten, D. \& Inman, R.A., 2011, 'The impact of timely information on organisational performance in a supply chain', Production Planning \& Control 18(4), 274-282. https://doi.org/10.1080/09537280701243926

Green, K.W., Zelbst, P.J., Vikram, J.M. \& Bhadauria, S., 2012, 'Green supply chain management practices: Impact on performance', Supply Chain Management: An International Journal 17(3), 290-305. https://doi.org/10.1108/13598541211 227126

Griggs, D., Stafford-Smith, M., Gaffney, O., Rockström, J., Ohman, M., Shyamsundar, P. et al., 2013, 'Sustainable development goals for people and planet', Nature 495(7441), 305-307. https://doi.org/10.1038/495305a

Gunasekaran, A., Subramanian, N. \& Rahman, S., 2015, 'Green supply chain collaboration and incentives: Current trends and future directions', Transportation Research Part E: Logistics \& Transportation Review 74, 1-10. https://doi. org/10.1016/j.tre.2015.01.002

Heras-Saizarbitoria, I., Landin, G. \& Molina-Azorin, J., 2011, 'Do drivers matter for the benefits of ISO 14001?', International Journal of Operations \& Production Management 31(2), 192-216. https://doi.org/10.1108/01443571111104764

Hoejmose, S., Brammer, S. \& Millington, A., 2012, 'Green supply chain management: The role of trust and top management in B2B and B2C markets', Industria Marketing Management 41(4), 609-620. https://doi.org/10.1016/j.indmarman. 2012.04.008

Huang, X., Boon, L.T. \& Xiaoming, D., 2015, 'An exploratory survey of green supply chain management in Chinese manufacturing small and medium-sized enterprises: Pressures and drivers', Journal of Manufacturing Technology 26(1), 80-103. https://doi.org/10.1108/JMTM-05-2012-0053

Kalane, L., 2015. 'Reasons for failure of SMEs in the Free State', Master's dissertation, University of the Free State Business School, University of the Free State South Africa, viewed 20 March 2018, from http://scholar.ufs.ac.za:8080/xmlui/ bitstream/handle/11660/4557/KalaneL.pdf?sequence=1\&isAllowed $=y$

Karatepe, O.M., 2006, 'Customer complaints and organizational responses: The effects of complainants' perceptions of justice on satisfaction and loyalty' International Journal Hospitality Management. 25(1), 69-90. https://doi.org/ 10.1016/j.ijhm.2004.12.008

Kengne, B.D., 2016, 'Mixed-gender ownership and financial performance of SMEs in South Africa: A multidisciplinary analysis', International Journal of Gender and Entrepreneurship 8(2), 117-136. https://doi.org/10.1108/IJGE-10-2014-0040

Kongolo, M., 2010, 'Job creation versus job shedding and the role of SMEs in economic development', African Journal of Business Management 4(11), 2288-2295.

Kumar, S., Chattopadhyaya, S. \& Sharma, V., 2012, 'A case study from Indian electrical and electronics industry', International Journal of Soft Computing and Engineering $1(6), 275-281$.

Lamming, R. \& Hampson, J., 1996, 'The environment as a supply chain management issue', British Journal of Management 7, 45-62. https://doi.org/10.1111/j.1467-8551.1996. tb00147.x

Laosirihongthong, T., Adebanjo, D. \& Tan, K.C., 2013, 'Green supply chain management practices and performance', Industrial Management \& Data Systems 113(8), 1088-1109. https://doi.org/10.1108/IMDS-04-2013-0164

Large, R.O. \& Thomsen, C.G., 2011, 'Drivers of green supply management performance: Evidence from Germany', Journal of Purchasing \& Supply Management 17(3), 176-184. https://doi.org/10.1016/j.pursup.2011.04.006
Lau, K. \& Wang, Y., 2009, 'Reverse logistics in the electronic industry of China: A case study' Supply Chain Management: An International Journal 14(6), 447-465. https://doi.org/10.1108/13598540910995228

Lee, S.Y., 2008, 'Drivers for the participation of small and medium-sized suppliers in green supply chain initiatives', Supply Chain Management: An International Journal 13(3), 185-198. https://doi.org/10.1108/13598540810871235

Leedy, P.D. \& Ormrod, J.E., 2015, Practical research: Planning and design, 11th edn., global edition, Pearson, Chicago, IL.

Lenny Koh, S.C., Demirbag, M., Bayraktar, E., Tatoglu, E. \& Zaim, S., 2007, 'The impact of supply chain management practices on performance of SMEs', Industria Management \& Data Systems 107(1), 103-124, https://doi.org/10.1108/ 02635570710719089

Li, G., Yang, H., Sun, L. \& Sohal, A.S. 2009, 'The impact of IT implementation on supply chain integration and performance', International Journal of Production Economics 120(1), 125-138.

Lindenberg, S. \& Steg, L., 2007, 'Normative, gain and hedonic goal frames guiding environmental behaviour', Journal of Social Issues 63, 117-137. https://doi.org/ environmental behaviour', Journal of

Liu, X., Wang, L., Dong, Y., Yang, J. \& Bao, C., 2011, 'Case studies of green supply chain management in China', International Journal of Economics and Management Engineering 1, 22-34.

Lu, L., Wu, C. \& Kuo, T.C., 2007, 'Environmental principles applicable to green supplier evaluation by using multi-objective decision analysis', International Journal of Production Research 45(18), 4317-4331. https://doi.org/10.1080/0020754 0701472694

Mafini, C. \& Muposhi, A., 2017, 'The impact of green supply chain management in small to medium enterprises: Cross-sectional evidence', Journal of Transport and Supply Chain Management 11(0), 270. https://doi.org/10.4102/jtscm.v11i0.270.

Maduku., D.K., Mpinganjira, M. \& Duh, H., 2016, 'Understanding mobile marketing adoption intention by South African SMEs: A multi-perspective framework', International Journal of Information Management 36(5), 711-723. https://doi. org/10.1016/j.ijinfomgt.2016.04.018

Matos, S. \& Hall, J. 2007, 'Integrating sustainable development in the supply chain The case of life cycle assessment in oil and gas and agricultural biotechnology', Journal of Operations Management 25(6), 1083-1102. https://doi.org/10.1016/j. jom.2007.01.013

Min, H. \& Galle, W., 1997, 'Green purchasing strategies: Trends and implications', Journal of Supply Chain Management 33(2), 10-17.

Min, H. \& Galle, W., 2001, 'Green purchasing practices of US firms', International Journal of Operations \& Production Management 21(9), 1222-1238. https://doi. org/10.1108/EUM0000000005923

Mitchell, M.L. \& Jolley, J.M., 1996, Research design explained, Harcourt Brace College, New York.

Mohanty, R.P. \& Prakash, A., 2014, 'Green supply chain management practices in India: A confirmatory empirical study', Production \& Manufacturing Research 2(1), 438-456. https://doi.org/10.1080/09537287.2013.832822

Mollenkopf, D., Stolze, H., Tate, W.L. \& Ueltschy, M., 2010, 'Green, lean, and global supply chains', International Journal of Physical Distribution \& Logistics Management 40(1), 14-41. https://doi.org/10.1108/09600031011018028

Montabon, F., Sroufe, R. \& Narasimhan, R., 2007, 'An examination of corporate reporting, environmental management practices and firm performance', Journa of Operations Management 25(5), 998-1014. https://doi.org/10.1016/j.jom. of Operations

Murphy, P. \& Poist, R., 2003, 'Green perspectives and practices: A comparative logistics study', Supply Chain Management: An International Journal 8(2), 122-131. https://doi.org/10.1108/13598540310468724

Neely, A., Gregory, M. \& Platts, K., 1995, 'Performance measurement system design: A literature review and research agenda', International Journal of Operations \& Production Management 15(4), 80-116. https://doi.org/10.1108/01443579510083622

Nyaga, G.N., Lynch, D.F., Marshall, D. \& Ambrose, E., 2013, 'Power asymmetry, adaptation and collaboration in dyadic relationships involving a powerful partner', Journa of Supply Chain Management 49(3), 42-65. https://doi.org/10.1111/jscm.12011

Odongo, W., Dora M., Molnár, A., Ongeng D. \& Gellynck, X., 2016, 'Performance perceptions among food supply chain members: A triadic assessment of the influence of supply chain relationship quality on supply chain performance', British Food Journal 118(7), 1783-1799. https://doi.org/10.1108/BFJ-10-2015-0357

Olorunniwo, F. \& Li, X., 2010, 'Information sharing and collaboration practices in reverse logistics', Supply Chain Management: An International Journal 15(6), 454-462. https://doi.org/10.1108/13598541011080437

Pretorius, M., 2009, 'Defining business decline, failure and turnaround: A content analysis', South African Journal of Entrepreneurship \& Small Business Management 2(1), 1-16. https://doi.org/10.4102/sajesbm.v2i1.15

Preuss, L., 2011, 'On the contribution of public procurement to entrepreneurship and small business policy', Entrepreneurship and Regional Development: An Internationa Journal 23(9),787-814. https://doi.org/10.1080/08985626.2010.546433

Ramukumba, T., 2014, 'Overcoming SMEs challenges through critical success factors: A case of SMEs in the Western Cape Province, South Africa', Economic and Business Review 16(1), 19-38.

Rao, P. \& Holt, D., 2005, 'Do green supply chains lead to competitiveness and economic performance?', International Journal of Operations \& Production Management 25(9), 898-916. https://doi.org/10.1108/01443570510613956

Rauer, J. \& Kaufmann, L., 2015, 'Mitigating external barriers to implementing green supply chain management: A grounded theory investigation of green-tech companies' rare earth metals supply chains', Journal of Supply Chain Management 51(2), 65-88. https://doi.org/10.1111/jscm.12063 
Rettie, R., Burchell, K. \& Riley, D., 2012, 'Normalising green behaviours: A new approach to sustainability marketing', Journal of Marketing Management 28 420-444. https://doi.org/10.1080/0267257X.2012.658840

Richey, R., Chen, H., Genchev, S. \& Daughert, P., 2005, 'Developing effective reverse logistics programs', Industrial Marketing Management 34(8), 830-840. https:// doi.org/10.1016/j.indmarman.2005.01.003

Rostamzadeh, R., Govindan, K., Esmaeili, A. \& Sabaghi, M., 2015, 'Application of fuzzy VIKOR for evaluation of green supply chain management practices', Ecological Indicators 49, 188-203. https://doi.org/10.1016/j.ecolind.2014.09.045

Sarkis, J., 2012, 'A boundary and flows perspective of green supply chain management' Supply Chain Management: An International Journal 17(2), 202-216. https://doi. org/10.1108/13598541211212924

Seroka-Stolka, O., 2014, 'The development of green logistics for implementing sustainable development strategy in companies', Procedia-Social and Behavioural Sciences 151, 302-309. https://doi.org/10.1016/j.sbspro.2014.10.028

Sheu, J.B., 2011, 'Bargaining framework for competitive green supply chains under governmental financial intervention', Transportation Research Part E 47, 573-592. https://doi.org/10.1016/j.tre.2010.12.006

Small Enterprise Development Agency, 2016, The small, medium and micro enterprise sector of South Africa, viewed 20 March 2018, from http://www.seda.org.za/ Publications/Publications/The $\% 20$ Small, $\% 20$ Medium $\% 20$ and $\% 20$ Micro $\% 20$ Enterprise $\% 20$ Sector $\% 20$ of $\% 20$ South $\% 2$ Africa $\% 20$ Commissioned $\% 20$ by $\% 20$ Seda.pdf

Srivastava, K.S., 2007, 'Green supply-chain management: A state-of-the-art literature review', International Journal of Management Reviews 9(1), 53-80. https://doi. org/10.1111/j.1468-2370.2007.00202.x

Srivastava, S.K., 2008, 'Network design for reverse logistics', Omega 36(4), 535-548. https://doi.org/10.1016/j.omega.2006.11.012

Sundram, V.P.K., Chandran, V.G.R. \& Bhatti, M.A., 2016, 'Supply chain practices and performance: The indirect effects of supply chain integration', Benchmarking: An International Journal 23(6), 1445-1471. http://doi.org/10.1108/BIJ-03-2015-0023

The Banking Association of South Africa, 2016, SME Enterprise, viewed 12 March 2018, from http://www.banking.org.za/what-we-do/sme/sme-enterprise/

Tiwari, M.K., Chang, P.C. \& Choudhary, A., 2015, 'Carbon-efficient production, supply chains and logistics', International Journal of Production Economics 194, 193-196. https://doi.org/10.1016/j.ijpe.2015.02.008

Urban, B. \& Naidoo, R., 2012, 'Business sustainability: Empirical evidence on operational skills in SMEs in South Africa', Journal of Small Business and Enterprise Development 19(1), 146-163. https://doi.org/10.1108/14626001211196451

Vachon, S. \& Klassen, R., 2007, 'Supply chain management and environmental technologies: The role of integration', International Journal of Production Research 45(2), 401-423. https://doi.org/10.1080/00207540600597781

Van Rensburg, S.L., 2015, 'A framework for green logistics for companies in South Africa', Master's dissertation, University of South Africa, viewed 15 March 2018, from http://uir.unisa.ac.za/bitstream/handle/10500/18750/thesis_jansen $\% 20 v a n \%$ 20rensburg_sl.pdf?sequence=1\&isAllowed=y

Walker, H., Di Sisto, L. \& McBain, D., 2008, 'Drivers and barriers to environmental supply chain management practices: Lessons from the private and public sectors', supply chain management practices: Lessons from the private and public sectors',
Journal of Purchasing \& Supply Management 14(1), 69-85. https://doi. org/10.1016/j.pursup.2008.01.007

Wang, Y., 2016, 'What are the biggest obstacles to growth of SMEs in developing countries? An empirical evidence from an enterprise survey', Borsa Istanbul Review 16(3), 167-176. http://www.elsevier.com/journals/borsa-istanbul-review/ 2214-8450/[2017
Westland, C., 2015, Structural equation models: From paths to networks, Springer, Berlin.

Whipple, J.M., Lynch, D.F. \& Nyaga, G.N., 2010, 'A buyer's perspective on collaborative versus transactional relationships', Industrial Marketing Management 39(3), 507-518. https://doi.org/10.1016/j.indmarman.2008.11.008

Wolf, E.J., Harrington, K.M., Clark, S.L. \& Miller, M.W., 2013, 'Sample size requirements for structural equation models: An evaluation of power, bias, and solution propriety', Educational and Psychological Measurement 76(6), 913-934. https:// doi.org/10.1177/0013164413495237

Wong, C.Y., Wong, C.W. \& Boon-itt, S., 2015, 'Integrating environmental management into supply chains: A systematic literature review and theoretical framework', International Journal of Physical Distribution \& Logistics Management 45(1) 43-68. https://doi.org/10.1108/IJPDLM-05-2013-0110

World Economic Forum, 2016, Insight report: The global competitiveness report 2015-2016, viewed 12 March 2017, from http://www3.weforum.org/docs/ gcr/20152016/Global_Competitiveness_Report_2015-2016.pdf/>

Wu, Z., Choi, T.Y. \& Rungtusanatham, M.J., 2010, 'Supplier-supplier relationships in buyer-supplier-supplier triads: Implications for supplier performance', Journal of Operations Management 28(2), 115-123. https://doi.org/10.1016/j.jom. 2009.09.002

Wu, Z. \& Pagell, M., 2011, 'Balancing priorities: Decision-making in sustainable supply chain management', Journal of Operations Management 29(6), 577-590. https:// doi.org/10.1016/j.jom.2010.10.001

Xie, Y. \& Breen, L., 2012, 'Greening community pharmaceutical supply chain in the UK: A cross-boundary approach', Supply Chain Management: An International Journal 17(1), 40-53. https://doi.org/10.1108/13598541211212195

Younis, H., Sundarakani, B. \& Vel, P., 2016, 'The impact of implementing green supply chain management practices on corporate performance', Competitiveness Review 26(3), 216-245. https://doi.org/10.1108/CR-04-2015-0024

Zailani, S.H.M., Eltayeb, T.K., Hsu, C.C. \& Tan, K.C., 2012, 'The impact of externa institutional drivers and internal strategy on environmental performance', International Journal of Operations \& Production Management 32(6), 721-745. https://doi.org/10.1108/01443571211230943

Zhu, Q., Qu, Y., Geng, Y. \& Fujita, T., 2015, 'A comparison of regulatory awareness and green supply chain management practices among Chinese and Japanese manufacturers', Business Strategy and the Environment viewed 25 March 2017 from http://onlinelibrary.wiley.com/doi/10.1002/bse.1888/abstract/

Zhu, Q. \& Sarkis, J., 2004, 'Relationships between operational practices and performance among early adopters of green supply chain management practice in Chinese manufacturing enterprises', Journal of Operations Management 22(3) 265-289. https://doi.org/10.1016/j.jom.2004.01.005

Zhu, Q., Sarkis, J. \& Geng, Y., 2005, 'Green supply chain management in China: Pressures, practices and performance', International Journal of Operations \& Production Management 25(5), 449-468. https://doi.org/10.1108/014435705 10593148

Zhu, Q., Sarkis, J. \& Lai, K.H., 2008, 'Confirmation of a measurement model for green supply chain management practices implementation', International Journal of Production Economics 111(2), 261-273. https://doi.org/10.1016/j.ijpe.2006.11.029

Zhu, Q., Tian, Y. \& Sarkis, J., 2012, 'Diffusion of selected green supply chain management practices: An assessment of Chinese enterprises', Production Planning \& Control 23, 10-11. https://doi.org/10.1080/09537287.2011.642188

Zobel, T., 2015, 'The impact of ISO 14001 on corporate environmental performance: A study of Swedish manufacturing firms', Journal of Environmental Planning and Management 59(4), 587-606. https://doi.org/10.1080/09640568.2015.1031882 